\title{
"A su usanza y según el aderezo de la tiera" - devoção e piedade barroca nas reduções jesuítico-puaranis
}

Eliane Cristina Deckmann Fleck*

Resumo. O artigo analisa o discurso jesuítico, através de suas falhas, apresentando as reduções jesuítico-guaranis (século XVII) como um espaço de reinvenção de significados, no qual se construiu uma sensibilidade própria, em conseqüência da apropriação seletiva e criativa e da ressignificação de expressões da cultura indígena guarani e da cultura cristã ocidental. Constata que as demonstrações próprias da sensibilidade guarani foram apropriadas pelo discurso jesuítico, na condição de resultantes do processo exitoso de conversão ao cristianismo.

Palavras-chave: Discurso jesuítico. Reduções jesuítico-guaranis. Cultura indígena guarani.

A historiografia produzida sobre as reduções jesuítico-guaranis é abundante e muito heterogênea, indicando tanto a importância desse fenômeno histórico, quanto a multiplicidade e o caráter polêmico das interpretações possíveis. ${ }^{1}$ Uma parte considerável dessa

*Eliane Cristina Deckmann Fleck é Doutora em História da América (PUCRS) e professora da Graduação em História e do PPG em História Latino-Americana da UNISINOS,

Anos 90, Porto Alegre, v. 11, n. 19/20, p.225-257, jan./dez. 2004 
"A su usanza y según el aderezo de la tiera"...

produção historiográfica considera que o acervo documental sobre as reduções jesuítico-guaranis, organizado pela Companhia de Jesus, "enuncia, por princípio, uma versão a partir da visão jesuítica", impedindo qualquer "possibilidade de se fazer uma leitura [...] extraindo da fala jesuítica uma leitura própria dos nativos do processo da conquista" (Resende, 1999, p.244-245). Além de nos oferecer visões estereotipadas dos indígenas guaranis, os historiadores têm se limitado, geralmente, "a repetir y comentar las descripciones de los cronistas de la época" sem aprofundar "las cuestiones teológicas, litúrgicas y pastorales que subyacen en tal modo de vida - la vida especificamente religiosa de las Reducciones" (Melià; Nagel, 1995, p.107). ${ }^{2}$

Assim, as condutas e manifestações da sensibilidade religiosa indígena registradas nessa documentação são consideradas como indícios da adesão aos valores cristãos ocidentais ou, ainda, como resultantes do processo exitoso de aculturação promovido pela Companhia de Jesus. Nossa proposta, no entanto, considerou que a documentação permite outros enfoques, na medida em que revela que aquilo que o jesuíta apresentava como indicativo da absoluta conversão pode ser tomado como uma ressignificação da tradição cultural guarani.

Para desvendar a peculiar sensibilidade religiosa reducional, propusemo-nos a analisar o discurso jesuítico ${ }^{3}$ referente ao século XVII, cobrindo o período de 1609 a 1675, através daquilo que Michel de Certeau chamou de "falhas" ou "lapsos na sintaxe construída", que, ao retornar nas "franjas", revela "resistências", "sobrevivências", enfim, aquilo "que pode perturbar o consagrado sistema de interpretação" (De Certeau, 1982, p.16).

A possibilidade de analisarmos as reduções jesuítico-guaranis nessa perspectiva apresenta-se na medida em que os registros jesuíticos enfatizam que as manifestações de devoção e de piedade religiosa foram pautadas, em sua maioria, por excessos de fervor emocional e disposição para perseverar nos novos padrões de sensibilidade e de conduta moral introduzidos pelos missionários. Gestos, tons de voz, expressões faciais, movimentos e posturas

Anos 90, Porto Alegre, v. 11, n. 19/20, p.225-257, jan./dez. 2004 
corporais e outras mensagens sobre estados emocionais dos indígenas são tomados e apresentados como indicativas de sua sujeição e passividade.

Em razão disso, as recorrentes informações sobre igrejas adornadas, altares erguidos e decorados, caminhos limpos, demonstrações de alegria e bailes "a su usanza" não parecem comprometer, no entendimento dos missionários, a devoção e a piedade expressas nas missas, procissões, festas religiosas e penitências. Afinal, "allí, donde antes no había sino madrigueras de fieras, ya no se ve sino un cielo lleno de ángeles en forma humana" (Leonhardt, 1927a, p.107), e "se ve en ellos grande fe; esta les asienta tan bien como si fueran ya cristianos viejos, y de muchos años de religión, $[\ldots]$ los tienen hoy nuestros padres tan domesticados y reducidos a la policía humana y divina que quien los ve no puede dejar de admirarse y dar mil gracias a Dios" (Documentos..., 1996, p.79).

As percepções que apontam para uma demonstração pública "da civilização dos afetos e da conduta" não parecem, igualmente, ser relativizadas, como fica demonstrado em outra passagem que consta da Carta Ânua de 1672 a 1675, segundo a qual "Bajaron de allí los pobres indios en masa, con manifestaciones de grande alegría, celebrando la llegada de los misioneros con bailes y música a su usanza" (Leonhardt, 1927c, p.25-26).

Autores como Guillermo Furlong, Antonio Astrain e Pablo Pastells valem-se dos registros dos Pes. Sepp, Cardiel, Peramás e Lozano para apresentar o êxito do processo reducional como única e exclusivamente decorrente do esforço dos missionários em adaptar a liturgia cristã "à índole própria dos Guaranis", devido "à notória mentalidade infantil dos índios Guaranis” (Jaeger, 1970, p.203-204). Na verdade, os missionários jesuítas estariam, segundo esses autores, desenvolvendo "as predisposições naturais dos indígenas, mediante formação e exercício", uma vez que "a primitiva civilização dos guaranis não possuía herança cultural" que pudesse ser agregada à liturgia cristã, além do que os índios, na opinião dos missionários, "tão pouco eram talentos criativos" (ibid., p.205). 
"A su usanza y según el aderezo de la tiera"...

Encontramos essa idéia na obra de Guillermo Furlong, que afirma que os jesuítas "[...] começaram por penetrar na psicologia do índio e, longe de adaptar os indígenas aos métodos europeus, adaptaram os métodos, que haviam aprendido no velho mundo, à idiossincrasia dos índios" (Furlong, 1962, p.308). O autor enfatiza, em razão disso, que os missionários teriam concluído acertadamente em valorizar a solenidade e a festividade que envolviam algumas celebrações litúrgicas, com a finalidade de servirem de "honesto entretimento" e para que "não lhes venha a tentação de fugir" e "lhes entrem as coisas de Deus" (ibid., p.490), uma vez que entre "estes índios saídos dos bosques, esse culto externo era ainda mais necessário, por seu crasso materialismo e apego às coisas visíveis e tangíveis" (ibid., p.273).

Neste estudo, tomamos as reduções jesuítico-guaranis como espaço de "mediação cultural", enfatizando sua expressão como "jogo de relações e de processos de construção de sentido", assumindo uma postura distinta daquela defendida por aqueles autores. A investigação que realizamos permitiu que constatássemos que os Guarani não reagiam apenas de forma passiva às novas condutas morais e aos princípios da fé cristã introduzidos pelos missionários. Os próprios registros que analisamos revelam as respostas criativas, ou seja, "a transformação criativa do que foi apropriado" (Burke, 1989, p.87), resultante do "empenho constante da integração da novidade no tradicional" (Cunha, 1987, p.101).

\section{"Para poner terror a otros"}

Em 1601, o Superior Geral da Companhia de Jesus decidiu reunir as regiões do Rio da Prata, Tucumã e Chile numa província independente, com o nome de "Paraguay". O $1^{\circ}$ Concílio do Rio da Prata, realizado em Assunção, em 1603, teve, nesse contexto, uma importância fundamental, por estabelecer as metas que deveriam ser alcançadas pelos missionários e as orientações e os meios que seriam empregados para "la enseñanza de la doctrina a los indios y la reforma de costumbres de los españoles” (Mateos, 1969).

Anos 90, Porto Alegre, v. 11, n. 19/20, p.225-257, jan./dez. 2004 
As determinações resultantes desse Concílio tornaram-se um referencial para o trabalho missionário, refletindo-se nas duas Instruções do Pe. Diego de Torres Bollo (1609 e 1610) ${ }^{4}$ aos missionários que atuavam junto aos Guarani no Paraguai. Essas Instruções renovavam as metas estabelecidas em 1603 e reforçavam orientações quanto à metodologia que seria empregada pelos missionários, enfatizando a necessidade de "tirar-lhes os pecados públicos e pô-los sob policiamento", bem como de afastar os feiticeiros, por serem muito perniciosos e incitarem os índios a permanecerem em suas superstições (apud Rabuske, 1978, p.25).

Os feiticeiros eram o alvo preferencial da ação catequética dos Jesuítas, como fica evidenciado na recomendação de que "repreendam nisso os culpados nos demais vícios públicos corrijamnos e os castiguem a seu tempo com amor e inteireza, especialmente os feiticeiros [...]" (apud Rabuske, 1978, p.27). Com efeito, os missionários já registravam, na Ânua referente ao ano de 1616, que os feiticeiros haviam influenciado "estas miserables almas a quienes ha hecho el demonio por medio de hechizeros creer que el Baptismo les mata y así rehusan el recivirlo" (Documentos..., 1924, p.76). Sob a ótica dos missionários, o demônio encontrava "fraudes com que entronizar a seus ministros, os magos e feiticeiros, a fim de que sejam a peste e ruína das almas", prejudicando o trabalho de conversão através dos incidentes por eles promovidos com a intenção de "[...] remedar em todas as partes o culto divino com ficções e embustes [...]" (Montoya, 1985, p.104).

O prestígio desfrutado pelos feiticeiros pode ser também avaliado por este registro, extraído da Carta Ânua de 1635-37, que revela, igualmente, a consciência que tinham os missionários do poder espiritual (de caráter sobrenatural) que exerciam esses feiticeiros sobre os indígenas, bem como da tradição ritualística que preservavam:

Acudieron, sin embargo, los infieles de todas partes, trayéndole presentes, para que les adivinase, los curase, y les procurase buena cosecha. Parecía a nuestros 
"A su usanza y según el aderezo de la tiera”...

Padres, que ésto era una grave rémora para la propagación de la fe, mucho más cuando corría el rumor de que los infieles pensaban en construir un templo, para este monstruo (Documentos..., 1924, p. 735$).^{5}$

Nesse sentido, vale observar que as imagens dos feiticeiros mais freqüentes nos registros são as que os identificam com demônios e realçam sua aparência monstruosa, ${ }^{6}$ como nesta referência ao feiticeiro Zaguacari:

Naquela redução [...] havia um índio vivo, que em sua existência e na disformidade de seu corpo, muito se parecia ao diabo. Chamava-se ele Zaguacari, que pretende significar o mesmo que "formosinho". Pouco, no entanto, lhe convinha este apelido, porque ele era de estatura muito baixa e tinha a cabeça apegada aos ombros e, para virar o rosto para trás, impunhase-lhe girar todo o corpo. Os dedos de suas mãos e pés imitavam não pouco os dos pássaros, pois eram torcidos para baixo. Só se viam as canelas em suas pernas, sendo que tanto nos pés como nas mãos ele possuía pouca ou nenhuma força (Montoya, 1985, p.146).

À presença ameaçadora dos demônios foi, no entanto, atribuída uma justificativa e, principalmente, uma função moral, como se observa nos registros feitos sobre os castigos que sobrevinham aos que roubavam, cometiam adultério ou deixavam de freqüentar a missa. O registro que transcrevemos informa ainda sobre a prática do exorcismo.

Num domingo, estando todos a ouvir o sermão e a missa, somente esse índio ficou em sua granja. Começaram então ali os demônios a dar vozes como de vaca, bramidos como de touro e mugidos como

Anos 90, Porto Alegre, v. 11, n. 19/20, p.225-257, jan./dez. 2004 


\section{Eliane Cristina Deckmann Fleck}

de bois, bem como imitar as cabras. Espantado, o pobre índio se recolheu a sua choça, sem se atrever a sair de lá, por tomado de medo. [...] O pior, contudo foi que [os demônios] deixaram toda aquela plantação amarelecida e como se um fogo a tivesse chamuscado no domingo seguinte aconteceu o mesmo. Revestime de sobrepeliz e tomei na mão a água benta e, em nome de Jesus Cristo [...] mandei-lhe [ao demônio] que fosse embora daqueles lugares e que em povo algum fizesse dano. Pus num copo fechado um pedaço da sotaina de Santo Inácio e nunca mais voltou o demônio (Montoya, 1985, p.102-103).

Em outra ocasião, Montoya (ibid., p.80) relata que presenciou a admoestação de cinco demônios a um jovem adoentado, sendo que "[...] A cabeça de um deles era de porco, a do outro de vaca e do mesmo estilo as dos demais. Tinham os pés de vacas, de cabras e pássaros enormes. Estavam com as unhas compridas, as pernas finíssimas e, despedindo de seus olhos raios como de fogo". O assédio do demônio era associado à reincidência nas antigas práticas rituais, como neste registro em que se informa também sobre o castigo divino que se abateu sobre os transgressores:

Unos cincuenta cristianos se habían ido a muy apartadas montañas para recolectar yerba. En el camino encontraron una enorme peña, un poco semejante a la figura de un hombre, llamado por los bárbaros aña ciba, es decir frente del demonio. A este monstruo de piedra ofrecen los infieles dones, para conseguir un feliz viaje [...] Pagaron muy caro su impiedad. Se enfermaron todos estos supersticiosos, y solos ellos muriéndose algunos y quedando los demás tan estropeados, que para un viaje de veinticuatro dias echaron meses enteros (Documentos..., 1924, p.693). 
"A su usanza y según el aderezo de la tiera"...

Para os missionários, eram os demônios que levavam os indígenas a cometerem pecado, reforçando a necessidade de mediante os sermões - torná-los "unos buenos luchadores en los combates contra los enemigos invisibles" para que pudessem "defenderse contra las tentaciones de parte de las malas pasiones, por medio del escudo de la fe y del santo temor de Dios" (Maeder, 1984, p.128-129). Cabe observar que "el indígena conformará su propia imagen del demonio cristiano", difundida pelos missionários jesuítas em seus sermões, aparecendo "con ocasionales figuras antropomórficas o zoomórficas” (Martini, 1990, p.336).

\section{"Para ganar más gracias sacramentales"}

Os sermões empregavam largamente os relatos edificantes e introduziam os indígenas nos mistérios da fé, atendendo à recomendação feita pelo Pe. Diego de Torres Bollo de que "[...] Sejam os sermões tais que se lhes declare algum mistério, artigo ou mandamento, repetindo-o muitas vezes e usando de comparações e exemplos" (apud Rabuske, 1978, p.26). Em razão disso, eram considerados meios privilegiados e eficazes para a conversão religiosa e para o comportamento virtuoso. A "boca do pregador" era identificada à "boca de Deus", sendo instrumento com que a graça manifestava-se e transformava os homens.

Em uma sociedade ágrafa como a Guarani, foram largamente empregadas imagens cristãs, como a do céu e do inferno, facilitando a percepção dos elementos básicos do cristianismo, bem como houve a implementação de uma estrutura perceptiva marcada por uma predisposição à materialização da sensibilidade religiosa. ${ }^{7}$ As visões e os sonhos dos indígenas registrados pelos missionários jesuítas estão evidentemente associados aos sermões, aos conselhos e às advertências feitas aos transgressores ou vacilantes, bem como às encenações teatrais que, constituindo-se em verdadeiros espetáculos de exaltação religiosa, predispunham os indígenas a externar publicamente suas culpas e seu arrependimento e louvor a Deus "para poner terror a otros" ou para demonstrar o "cambio de sus sentimientos". Os

Anos 90, Porto Alegre, v. 11, n. 19/20, p.225-257, jan./dez. 2004 
missionários valeram-se amplamente da imaginação para atingir estados almejados de emoção religiosa, inculcando medo e horror através das alegorias celestiais.

[...] muito conveniente era fazer-se alguma boa demonstração pública, para confusão dos sacerdotes desses ídolos e desengano dos povos [...]. Reunida toda gente na igreja, fez-se-lhe um sermão, em que se tratou do verdadeiro Deus, da adoração que lhe é devida da parte das criaturas, e dos enganos do demônio $[\ldots]$ das mentiras e ardis dos magos [...]. Tirado esse estorvo, aquela gente começou a freqüentar com assiduidade a igreja, e os cristãos a confissão" (Montoya, 1985, p.108-109).

A permanente luta entre o bem e o mal manifesta-se no discurso missionário jesuítico, opondo o céu ao inferno e os anjos ao demônio, como se pode observar nesta passagem extraída da Ânua de 163739, na qual o padre narrava que "permitió que los demonios molestasen al enfermo, llevándolo en aparencia a los fuegos eternos. $\mathrm{Al}$ instante aparecieron dos ángeles para sacarlo de las garras del demonio" (Maeder, 1984, p.122).

Os sonhos registrados pelos missionários apresentam, de forma recorrente, indígenas realizando exames de consciência e purificação espiritual através do sacramento da confissão dos pecados.

Una india de muy mala vida, estaba tan obstinada que huía de la confesión. Dios tuvo misericordia de ella, sin que ella diera ocasión para ello. Vio ella, como después contó, a un hermoso niño, que la conducía por medio de unos precipicios hasta un pozo muy profundo y terrible, de donde salían tristes gemidos y horribles aullidos. Vio allí unos monstruos negros, que revoloteaban por unas espesas nieblas y el fuego que estaba chisporroteando en los abismos. Entonces dijo el niño a la india: Allí te echarán abajo, si no te 
"A su usanza y según el aderezo de la tiera”...

arrepentes de tus pecados tan sucios, y no te confiesas. Desapareció el niño y la india se despertó. Al amanecer se apresuró a ir a la iglesia, contó lo que había visto, y con gran dolor de su alma se confesó de sus pecados (Maeder, 1984, p.96).

A visão do Inferno presente no sonho dessa indígena é descrita com colorações tão vivas que o temor que possa ter produzido nela deve ter ocasionado não só sua confissão, mas a internalização da permanente ameaça de experimentá-lo concretamente. As Cartas Ânuas permitem-nos ainda avaliar o impacto dos sonhos e das visões sobre as condutas dos índios reduzidos:

Obstinadamente siguió aquel joven en su mala vida, haciendo con sangre fría las más grandes barbaridades. La misericordia de Dios, empero, había resuelto sacudir aquel corazón endurecido. Estaba una vez durmiendo, cuando se vio puesto, por medio de unos demonios, delante del tribunal del Eterno Juez. Siguió el sumario y se pronunció la sentencia. Sintióse el joven azotado barbaramente por los demonios, y cuando despertó, le atormentó el dolor en todo su cuerpo que no pudo levantarse. El gran sufrimiento le hizo volver a buen juicio y arrepentirse de veras. Llamó el Padre e hizo una larga y buena confesión. Sanó en alma y cuerpo, y persevera en el buen camino (Maeder, 1984, p.34).

Há, também, o registro de uma indígena que, debilitada por complicações decorrentes de um parto, desfalece e sonha. O missionário não descuidou de valorizar a "morte aparente" e a fanática conversão que se seguiu:

En su mocedad esta india despues de averle muerto dos hijuelos ahogo al ultimo trance de la vida de un reveçado parto, dispuso sus cosas como quien en fin

Anos 90, Porto Alegre, v. 11, n. 19/20, p.225-257, jan./dez. 2004 


\section{Eliane Cristina Deckmann Fleck}

conocía era llegada su hora y delante de muchos que la asistían perdió los sentidos y quedó como muerta por tal la juzgaron los circunstantes por grande espacio de tiempo aunque ella no sabe o que verdaderamente en esto pasó, mas de que en este tiempo y sin parecerle se avia apartado de donde estaba, se halló en un lugar eminente de donde la subieron por unas gradas y en lo alto de ellas estava una casa toda fabricada de oro y queriendo entrar por la puerta descubrió desde ella gran muchedumbre de gente y un altar y unos Padres con el traje de la Compañía y a sus dos ijuelos difuntos que asistían sirviendo a los dos lados los cuales acusaron la madre que no sabía las oraciones y que assi no devia franquearsele la entrada [...] en la qual se volvió a Nuestro Señor invocando su favor y repitiendo muchas vezes: Madre de Dios, Madre de Dios en su aiuda con lo qual se cobró del arrobamiento y paracismo y en breve sanó de su achaque, quedando tan aficionada a las cosas divinas que agora vieja como es va de un pueblo a outro por asistir a los misterios de la misa donde saben que se celebran (Maeder, 1984, p.34-35).

A crença nas aparições das almas do Purgatório que vinham pedir aos vivos missas e orações para a reparação de erros por elas cometidos fica assim documentada:

Aviendose una mujer ya defunta aparecido a su marido le mando fuese al Pe a pedirle de su parte una misa hiçolo el hombre: prometiose la el Pe mas olvidado quando estaba en el altar ofreciola por otra intención, reparando a la noche en su descuydo le salteo algun recelo no fuese el alma de la difunta a darle el recuerdo al ponto le tocaron a la puerta y entendio claramente que aquella alma le pedia su socorro dixole la misa y no volvio más. Otra vez estando solicito por la salvacion de un penitente suyo defunto se le mostro,

Anos 90, Porto Alegre, v. 11, n. 19/20, p.225-257, jan./dez. 2004 
“A su usanza y según el aderezo de la tiera”...

durmiendo el Pe, con rostro risueño y preguntando de su estado en la vida le dixo si no fuera bueno no me vieras con esta alegria (Documentos..., 1924, p.259).

Em vários relatos que referem visões e sonhos de moribundos, encontramos a associação entre os sacramentos e a "boa morte", que revela a presença do universo simbólico jesuítico e o processo de produção e difusão de representações nas reduções. Deve-se considerar, no entanto, que não se trata de uma simples transposição de representações, mas que esses relatos indicam a "construção" de representações sociais num novo contexto, o reducional, por novos agentes sociais, os índios Guarani. Esse processo, no qual os missionários manejaram símbolos e valores, definindo sua direção e assimilação, foi condicionado às motivações e às aspirações dos indígenas.

\section{"Para el cambio de sus sentimientos"}

Significativas para a análise da construção dessa peculiar sensibilidade religiosa são estas passagens extraídas das Cartas Ânuas referentes ao período de 1610-1613, fase inicial da implantação do modelo reducional, e que registram o medo dos indígenas de morrerem infiéis e de irem para o Inferno em razão disso.

Han tenido ordinariamente sermones de doctrina xpana. [...] El medio que tomo Dios nro. Sr. para que estos entrasen en fervor en pedir el baptismo fue, que acabandoles de predicar un día en que se les trató de los bienes grandes del baptismo, se levanto un niño de doçe a treçe años y hincado de rodillas y puestas las manos pidio por amor de Dios le baptizasen, diciendo temia mucho morirse infiel e irse al infierno, y asi queria ser hijo de Dios por el bautismo e irse al cielo, y haviendole dado el si, daba saltos de placer y gozo, diçiendo a todos que el pe. le queria haçer hijo de Dios (apud Pastells, 1912, p.164).

Anos 90, Porto Alegre, v. 11, n. 19/20, p.225-257, jan./dez. 2004 
É conveniente ressaltar que, na avaliação dos missionários, o temor da morte sem a confissão e sem a absolvição dos pecados e a perene ameaça do Inferno levavam os indígenas a procederem de acordo com suas recomendações. O relato constante na Ânua de 1637-1639 informa:

Hubo uno que se adelantó tanto en su temeridad que ni siquiera respetaba el Sacramento de la Confesión. Pero no impunemente había provocado a Dios. Se enfermó gravemente. [...] Sus parientes temían que se les iba a morir y al mismo tiempo que se condenase eternamente, ya que se hizo el desentendido a todos sus caritativos consejos. [...] Así murió impenitente y fue sepultado en el infierno, para servir de horrible escarmiento a los indios de la reducción. [...] por justo juicio de Dios fue privado en la hora de la muerte de los consuelos de la religión (Maeder, 1990, p.91).

Nos relatos que referem a administração do sacramento do batismo a moribundos, encontramos uma vinculação com a garantia da salvação:

$[\ldots]$ estando dando gracias vino su hijo a llamarme a gran priesa, que su madre se queria baptizar. Fui y vi en ella eficasia de los medios divinos hallandola tan trocada que me espante. Pidiome la baptizasse e instruyda en los misterios de nra santa fe y arepentiendose de sus peccados recebido el baptismo murio (Documentos..., 1924, p.77).

O apego à confissão também remete-nos à absorção de sua eficácia mecânica pelos indígenas, como revela este trecho da Carta Ânua de 1637-39:

Es una excepción entre tanta gente, que alguien no quiera saber nada de confesión pues, los más son muy

Anos 90, Porto Alegre, v. 11, n. 19/20, p.225-257, jan./dez. 2004 
"A su usanza y según el aderezo de la tiera”...

aficcionados a ella, y no soportan la dilación cuando, por ejemplo, el confesor no acude pronto, retenido por un asunto importante que en aquel instante le ocupa. Temen la muerte imprevista y urgen para que sean oídos en confesión luego, aunque a veces no tienen nada de importancia que confesar, o lo hayan confesado ya tantas veces, haciendo esto, para ganar más gracias sacramentales (Maeder, 1984, p.96).

A observação do Pe. Zurbano, de que os indígenas se confessavam "para ganar más gracias sacramentales" e que "son muy aficcionados" à confissão, não o impediu de afirmar que "muy inclinados son los indios a hacer malas confesiones, lo que se comprende tomando en cuenta su rudeza e incapacidad para profundizar sus conocimientos religiosos" (Maeder, 1984, p.34). Em relação ainda às "buenas confesiones" e às "malas confesiones", cabe observar que se constituíram em preocupação recorrente dos missionários, como pode ser observado na Ânua de 1668:

Fue preguntado en el tribunal de la penitencia cierta mujer, si no tenía otros pecados más. Había sucedido esto ya tres veces, negándo ella los pecados, y recibiendo tres veces la absolvición invalidamente, aunque estaba gravemente enferma, y próxima a morir. Felizmente recobró ella el ánimo para confesarse bien, y declaró que la causa de su malestar eran sus malas confesiones, viéndose ella perseguida de noche por un perro de terrible aspecto, lo cual le había perturbado más todavía. Después de haberse confesado, como convenía, murió (Leonhardt, 1927c, p.20).

Deve-se observar que, na mesma Carta, são mencionadas repetidas confissões e as razões apontadas pelos indígenas para tal prática. Sentimentos de "vergüenza" e "humillación" são expressões

Anos 90, Porto Alegre, v. 11, n. 19/20, p.225-257, jan./dez. 2004 
constantes dos registros, indicando a interiorização de responsabilidade moral não-identificada com a cultura e a ética guaranis. É provável que a humilhação sentida, ao se confessarem com vários confessores, levasse-nos a realmente abandonar as condutas indesejáveis, evitando, com isso, repetir a situação de constrangimento. Deve-se ter em conta, no entanto, que o que os movia à confissão era a promessa da absolvição dos pecados que garantiria as bênçãos divinas e os livraria dos infortúnios.

Decorridos alguns anos, o Pe. Juan Ferrufino deixava entrever, em suas observações na Ânua de 1647-49, que a tarefa da conversão não estava concluída e que as adversidades continuavam tendo uma função "educativa", devendo-se, por isso, manter as mesmas estratégias de conversão:

[...] sí como se ve en la naturaleza que la siembra se arraiga más por el cierzo, y el arbol por el huracán. Así las cosas grandes se solidifican más por la adversidad. [...] Esperamos, empero, que se convertirán por medio de nuestra solicitud y en consecuencia del remordimiento de su conciencia. Procuramos ganar su voluntad con favores, aunque nos hayan hecho tanto mal [...] (Leonhardt, 1927c, p.155)

A necessidade de constantemente fazê-los sentir "el remordimiento de su conciencia", além de indicar a freqüência com que ocorriam desvios de conduta ou transgressões, atesta o senso de oportunidade (ou, como preferem os missionários, por "inspiracion sensible") dos jesuítas, que utilizavam os sermões para instar os indígenas ao "bom comportamento": 8

Otro hombre perverso por largo tiempo supo ocultar el veneno de sus pecados que le consumía, y parecía irremediablemente perdido, ya que sacrilegamente recibía los sacramentos. Un día vía como predicaba uno de los Padres Misioneros contra el crimen de la 
"A su usanza y según el aderezo de la tiera”...

hipocresía y de ocultar pecados en la confesión (pues, como por inspiración se le había ocurrido predicar sobre esta materia). Causóle a aquel infeliz tanto dolor que le costó contenerse para no con alaridos manifestarse como el hombre mas perdido del mundo. Luego despues del sermón se puso a llenar tres hoyas de papel con las listas de sus pecados, entre torrentes de lágrimas. Echóse a los pies del confesor y le entregó el papel entre muchos sollozos y bañado de lágrimas, desmayándose casi de dolor y arrependimiento. Libróle el confesor de la carga de su conciencia y desde aquel tiempo vivió con mucha edificación (Leonhardt, 1927c, p.77).

Os registros feitos pelos missionários parecem indicar, realmente, uma alteração significativa nas atitudes dos indígenas:

Ay tan grande frecuencia de sacramentos, en especial de la penitencia que comúnmente no pueden los padres dar oídos a tantos. Con el de el altar tienen tan grande fe y devoción, que se previenen mucho antes para recivirle. $Y$ a este temor es el provecho que sacan de la divina mesa, que campea en sus costumbres $\mathrm{y}$ se han visto en materia de honestidad muchos y muy illustres exemplos [...] Y si alguna vez por la malícia del demonio han caido se han impuesto de su voluntad muchas penitencias muy graves y dados extraordinarias muestras de dolor que todos son buenos indicios de las veras con que se han dedicado al Señor estos nuevos cristianos. [...] Cada día se juntan todos a rezar de comunidad el rosario, oir misa, dezir la letania de la Virgen y resplandecen entre todos con la inocencia devida, por lo qual hazen grande instancia para ser admitidos (Maeder, 1990, p.125).

A moderação das emoções, a normatização de ações e a eliminação de comportamentos inconvenientes ficam evidenciadas

Anos 90, Porto Alegre, v. 11, n. 19/20, p.225-257, jan./dez. 2004 
nas referências à observância dos códigos de postura corporal, tais como os de curvar-se diante do santo em sinal de respeito, baixar a cabeça como forma de aceitar uma ordem, caminhar de uma determinada forma em procissão e ocupar um lugar específico dentro da igreja, durante a missa.

\section{"Para el remordimiento de su conciencia"}

A preparação para as festividades e procissões e os rituais de purificação mereceram também atenção nos relatos dos missionários ao Provincial. Nas Cartas, dá-se notícia da firme conversão dos indígenas, registrando também a eliminação dos "restos de paganismo" e informando sobre a integração dos convertidos às práticas religiosas, por efeito das ações normatizadoras. A "Conquista Espiritual" traz duas situações bastante significativas para o estudo dessas práticas e das representações que as legitimavam. A primeira faz referência ao aspecto das igrejas e festas organizadas "com devoção e asseio", uma associação que sugere não só o "enquadramento religioso", mas também a assimilação de padrões de higiene e conduta civilizada.

Fizeram-se igrejas de fácil construção, de grande capacidade ou espaço e vistosas, e renovaram-se os instrumentos musicais [...] Nelas colocamos o Santíssimo Sacramento, cuja festa - o "Corpus Christi” - se comemora com pobreza, mas também com devoção e asseio. Preparam os índios os altares (especiais para dita festa), e fazem os seus arcos!, [sic] nos quais penduram os pássaros do ar, os animais do mato e os peixes da água [...] (Montoya, 1985, p.144).

$\mathrm{Na}$ segunda, destacam-se as descrições que Montoya faz da preparação espiritual que antecedia as festas religiosas, marcada pelo jejum, pela penitência e, sobretudo, pela tensão interior - a angústia - que levava à demonstração pública de arrependimento e à confissão.

Anos 90, Porto Alegre, v. 11, n. 19/20, p.225-257, jan./dez. 2004 
"A su usanza y según el aderezo de la tiera”...

Ao raiar do dia assistem missa o ano todo e, depois de haverem estado na igreja, dirigem-se ao trabalho, que obtém bons resultados a partir da preparação tão religiosa. [...] Comungam os que têm capacidade quatro vezes no ano em que há jubileu, sendo preparados para tanto com sermões e exemplos, jejuns, disciplinas e outras penitências! (Montoya, 1985, p.169).

Sobre as freqüentes referências às "demostraciones de sentimientos", há uma passagem que trata da morte de um missionário, ocasião em que se observou "un lastimoso alarido" e "un funestisimo llanto" (Maeder, 1990, p.48).?

Los indios que con la pena de ver puesto a su Padre en aquel trance no sosegavan, se avian juntado muchos y tenían en aquella sazón cercada nuestra casa, dioles aviso de la muerte el doble de las campanas, y alçaron todos un lastimoso alarido, siguiendole luego todos los demás que estavan esparcidos por las rancherías del pueblo en los quales se oían tales extremos de sentimiento y de funestisimo llanto, que representavan quanto a esto uno de aquellos días confusos y temerosos que han de anteceder al del juicio [...] (Maeder, 1990, p.48).

Pode-se sugerir que o "chorar copioso" esteja vinculado tanto à encenação ritual, quanto à consciência da culpabilidade e à necessidade de demonstração pública de arrependimento, como fica atestado nestes trechos da Ânua de 1632-1634:

Mas el Padre penetrando blandamente sua corazones sus amorosas palabras, les hizo volver en sí, y que se dispusiesen en aquel riguroso trance con mucha penitencia y lágrimas, acavaron todos confesando sus

Anos 90, Porto Alegre, v. 11, n. 19/20, p.225-257, jan./dez. 2004 


\section{Eliane Cristina Deckmann Fleck}

delictos, y deseando muy seguras prendas de la misericordia, qu el señor avia usado con sus almas (Maeder, 1990, p.48).

Neste registro que selecionamos, é feita referência ao costume da "saudação lacrimosa" guarani, apresentada aqui como manifestação de caridade e comoção:

En el momento de encontrarse, quedaron tan conmovidas ambas partidas, que largo rato no podían hablar, sino sólo llorar, hasta que al fin se saludaron mutuamente según su costumbre propia, abrazándose con efusión, y sacando en seguida los refrescos y las provisiones. Era un espectáculo ternísimo (Maeder, 1984, p.93).

A “civilização das condutas"10 destacada pelos missionários é acompanhada de manifestações de fervor e de devoção, demonstradas no "chorar copioso" durante a assistência às missas e na prática de penitências e de autoflagelação. ${ }^{11}$ Vale lembrar a insistente recomendação de que os indígenas assistissem às missas, já que, para os missionários, a "adesão corporal" a essas cerimônias evidenciava uma "adesão espiritual". ${ }^{12}$ Em razão disso, os indígenas ausentes à missa e omissos na observância dos rituais de exteriorização da fé eram punidos com castigos físicos ou divinos. ${ }^{13}$

Cabe lembrar aqui que uma das características essenciais do cristianismo colonial era a exteriorização, do que resultava uma percepção religiosa altamente simbolizada, ligada mais à imagem do que àquilo que estava sendo representado. Trata-se, pois, de considerar que os corpos e sua gestualidade tanto são expressão e lugar de inscrição da cultura, quanto objetos de análise e de exercício do poder, afinal "não há direito que não se escreva sobre os corpos [...] [o direito] domina o corpo" (De Certeau, 1994, p.231).

Anos 90, Porto Alegre, v. 11, n. 19/20, p.225-257, jan./dez. 2004 
"A su usanza y según el aderezo de la tiera"...

As técnicas de inculcação de condutas e normas corporais e de controle dos gestos encontram-se registradas na documentação jesuítica que analisamos, a qual descreve as condutas prescritas e as transgressões exteriorizadas. Como bem observa Revel, no exercício da civilidade cristã, "o que mais importa é o que se vê", logo, a conduta deve "evidenciar em seus gestos, a dupla exigência de um decoro que é indissoluvelmente civil e cristão" (Revel, 1991, p.186187). Essa percepção transparece claramente neste registro que integra a Ânua de 1637-1639, a qual, além de qualificar como justos os castigos divinos, define o que era considerado transgressão: "El castigo era muy justo, porque ya eran cristianos, y no obstante querían vivir a manera de los gentiles, vagando por los campos, olvidando o despreciando las prácticas religiosas" (Maeder, 1984, p.90).

A Ânua referente aos anos de 1641 a 1643 informa sobre como eram identificados os transgressores e como se procedia para determinar as penitências.

Los domingos y fiestas se celebran con toda solemnidad, misa cantada y sermón, y antes doctrina a todo el pueblo, y por la tarde volviéndose a juntar dan los fiscales cuenta de los que han faltado en la semana a misa y a doctrina y se les da una suave penitencia que ellos reciben con extraña sujeción y rendimiento [...] A uno se le dio una penitencia a su parecer pequeña, y así reclamó con sollozos, Padre más, esto es poco [...] (Documentos..., 1996, p.7779).

Em relação aos novos padrões de conduta, deve-se salientar os relacionados com a sexualidade e a adoção da monogamia. O Pe. Francisco Lupercio de Zurbano registra a rigorosa disciplina e os excessos cometidos por um índio que se impôs a autoflagelação:

Sucedió que cierto joven, molestado por la tentación, se echó en un hormiguero. Ya bastante maltratado

Anos 90, Porto Alegre, v. 11, n. 19/20, p.225-257, jan./dez. 2004 


\section{Eliane Cristina Deckmann Fleck}

por esto, se revolvó entre punzantes ortigas. Enfermose por esto, y fué refrenado en sus penitencias por nuestros Padres. Contestó él: No importa. Prefiero morir antes que pecar. [...] Señales son estas que ya está profundamente arraigado en su corazón el santo temor y amor de Dios (Maeder, 1984, p.129).

A Carta Ânua de 1637-1639 refere o arrependimento de um jovem após não ter conseguido controlar sua libido e a forma como procurou penitenciar-se:

Cierto joven havía caído imprevistamente en un pecado carnal. Le dolió tanto, que comenzó a tratar cruelmente su cuerpo con diferentes clases de asperidades, no dejando ni la cara sin su especial suplício. Así preparado, se acercó al tribunal de la penitencia, profundamente conmovido por el dolor y arrepentimiento (Maeder, 1984, p.102-103).

Decorridos mais de quarenta anos, a Ânua de 1668 ainda refere a prática da autoflagelação, destacando o rigor e o entusiasmo com que os indígenas a executavam:

En su gran compasión con la Sagrada Pasión de Cristo nuestro Señor, toman ellos con entusiasmo sangrientas disciplinas; y en la Semana Santa sucedió que, acompañando alguno en la procesión la grande Cruz, amarrado a ella con una larga soga, enlazada en sus manos, se hizo disciplinar con azotes de puas, hasta que, ya al entrar otra vez en el templo, lo descubrió uno de los Padres, y lo prohibió, haciendo curar las heridas del penitente (Leonhardt, 1927c, p.16).

A internalização da noção de pecado e de culpabilidade chegava a extremos, como neste registro extraído da Conquista Espiritual, que refere tanto a prática de flagelação, quanto a de exorcismo:

Anos 90, Porto Alegre, v. 11, n. 19/20, p.225-257, jan./dez. 2004 
"A su usanza y según el aderezo de la tiera”...

Havia meses que estava doente um moço de vida muito correta [...]. Viu o moço diante de si um etíope desnudo, o qual levava numa sacola alguns ossos de defunto $[\ldots]$ assim o demônio foi-se aproximando dele $[\ldots]$. Pediu o enfermo que me chamassem. Entretanto, vendo-se ele atormentado de tal forma pelo hóspede, solicitou a seu pai que com força o açoitasse, pois com isto sairia dele aquela besta. $\mathrm{O}$ amor paterno fê-lo rejeitar semelhante ação, mas a mãe, julgando bom o remédio, agarrou umas cordas e começou a flagelar o filho. Ao mesmo tempo pedialhe este que ela batesse com energia, e ao demônio ordenava que saísse. Por fim, depois de várias demandas e respostas, saiu, deixando moído o pobre rapaz (Montoya, 1985, p.161).

Apesar de registrarem como exageradas as manifestações de penitência a que os índios submetiam-se, os missionários não escondiam sua satisfação em relação a elas, interpretando-as como internalização da noção de pecado e de responsabilidade moral. A Ânua de 1663-66 reforçaria os efeitos benéficos da prática da penitência, associando-a à abundância e à fertilidade da terra e à garantia de bênçãos:

La saludable penitencia, que se hace de antemano, previene la satisfacción que nos queda por hacer. Pues, ya estaba la peste asolando los pueblos circunvecinos, y no se atrevió a atacar precisamente este pueblo, defendido por la penitencia, y se detuvo como espantada de su vista. La tierra, empero, humedecida por la sangre derramada por los azotes, que a su vez surcaban los cuerpos, comenzó a producir una riquísima cosecha, mucho más grande que la de las otras reducciones, castigadas por la sequía, así que este pueblo pudo generosamente socorrer a los hambrientos de otra parte (Leonhardt, 1927c).

Anos 90, Porto Alegre, v. 11, n. 19/20, p.225-257, jan./dez. 2004 
O medo da doença e, sobretudo, o medo da morte introduzidos pelos missionários através dos sermões e da doutrina traduziram-se em padrões de comportamento e de sensibilidade pautados por manifestações de devoção e de piedade, exaustiva e entusiasticamente descritas pelos missionários. O temor da morte sem a confissão e sem a absolvição dos pecados e a perene ameaça do Inferno levavam os indígenas a proceder de acordo com as recomendações dos missionários, tanto em razão de medos reais (pestes, fome, ataques de bandeirantes), quanto em decorrência dos medos potenciais, construídos a partir da pregação jesuítica. As Cartas Ânuas de 16371639, por exemplo, referem que, em face da ameaça dos bandeirantes, os indígenas apressavam-se em solicitar o batismo e a confissão "para poder pelear com más tranquilidad" (Maeder, 1984, p.72) e que "cada vez, antes de tirar el proyectil, se hincan de rodillas y se persignan" (ibid., p.79) e, ainda, que dirigiam "frecuentes plegarias a la Santísima Virgen, para que conseguieran una completa victória, como la conseguieron" pela "devoción de las mentes piedosas hacia de la Virgen" (ibid., p.94).

O registro selecionado pelo redator da Carta Ânua, o Provincial Pe. Francisco Lupercio de Zurbano, prossegue referindo que os indígenas realizaram uma procissão que levava "en triunfo la imagen de la Virgen por calles y plaza, por debajo de los arcos artisticamente adornados com flores y ramas del campo, entre súplicas y cánticos sagrados" (ibid., p.93-94). Apesar de observar que, após se terem confessado e feito batizar, os Guarani "ardian en deseos de comenzar la batalla" (ibid., p.73), o Pe. Zurbano ressalta que, considerando "el natural bárbaro y feroz de esta gente y su antiguo carácter rastrero" (ibid., p.80), "estas sus prácticas religiosas parecerán, no pequeñeces, sino cosas grandes, no vilezas, sino cosas sublimes, a lo menos delante de Dios, el cual sabe apreciarlas en su justo valor" (id.). Essas manifestações, próprias da sensibilidade guarani, são descritas em Cartas Ânuas anteriores, como as de 1641 a 1643, que apontam para um comportamento arraigado e consentido pelos missionários: 
“A su usanza y según el aderezo de la tiera”...

Los domingos y fiestas se celebran con toda solemnidad, misa cantada y sermón [...] en las iglesias que están muy bien adornadas con el adorno posible según el aderezo de la tierra [...] Cuando hacen señal para llevar el Santísimo al doliente aderezan la casa deste con flores, barren y componen las callles con ramos, y todos comúnmente traen sus velitas de cera silvestre y acompañan al señor con gran devoción y música de chirimía (Documentos..., 1996, p.77).

Aspectos como os revelados por essas passagens das Ânuas ressaltam, de forma significativa, os lapsos no discurso jesuítico, na medida em que registram, aparentemente sem comprometimento da avaliação positiva sobre "aquella inculta gentilidad", índios domesticados (convertidos) mantendo "danzas y saraos a su modo":

Unos vinieron bogando el Paraná abajo en casi 200 canoas muy de fiesta y a su usanza; otros por tierra salieron a recibirnos con danzas y sarao a su modo; levantaron muchos altares, haciendo cada reducción el suyo ricos con la pobreza de la tierra. A trechos estaban fabricados arcos triunfales cuyo adorno era extraño: tenían dellos pendientes pescados asados y crudos, y carne cruda y asada, pollos en jaulas, gallina colgadas, huevos y perdices, micos y zorros, perros y gatos, pellejos de animales llenos de paja, zurrones de cuero llenos de comida, cestos de algodón, usos con mazorca de lo mismo, rosarios y calabazos, arcos y flechas, y cosas semejantes que son las que suelen colgar en sus mayores fiestas, y viendo cuan grande nos la hacían a su usanza en muestras de agradecimiento les repartí donecillos que ellos estiman mucho, como anzuelos, alfileres, agujas, cuentas azules, cuchillos y camisetas, y las iglesias algunas casuelas y frontales, quedando tan admirado como consolado de ver en medio de aquella inculta gentilidad el culto divino tan en su punto, los altares

Anos 90, Porto Alegre, v. 11, n. 19/20, p.225-257, jan./dez. 2004 
tan aseados, la musica tan excelente, los indios tan domesticados, las indias y los niños tan bien enseñados con los afanes y sudores de los Padres, todos los cuales me hicieron después en particular en cada una de sus reducciones gran fiesta, y recibieron con singular caridad, consolándome no poco de verlos [...] (Documentos..., 1996, p.76).

Na verdade, as concessões perceptíveis nas "falhas do discurso jesuítico" indicam que os missionários tiveram não somente a consciência de sua necessidade "para atraerlos mejor con estas novedades y prodigios al suave jugo de su ley evangelica y reformación de suas bárbaras costumbres" (Documentos..., 1996, p.122), mas também reconheceram "la particularidad que tiene esta nueva iglesia" (Maeder, 1984, p.74). Demonstram, igualmente, que os indígenas Guarani encontraram, nas reduções, um espaço privilegiado para continuarem sendo Guarani, o que é admitido pelos próprios missionários jesuítas ao registrarem que "[...] se les reciben con cariño [...] y se les libran de otro cautiverio peor, dándoles por la fe la libertad de los hijos de Dios" (Leonhardt, 1927c, p.33).

\section{"A su modo y usanza"}

A ação missionária jesuítica constitui-se em objeto privilegiado para a compreensão histórico-antropológica dos mecanismos simbólicos empregados nos processos de mediação cultural. Se, por um lado, o discurso missionário revela-nos o universo simbólico jesuítico e sua difusão nas reduções jesuítico-guaranis, por outro lado, os sonhos, visões, batismos, confissões, curas milagrosas e ressurreições apontam para uma "convergência de horizontes simbólicos". Os relatos acentuam a tensão emocional, a atmosfera trágica e o ardor carismático que envolviam as missas, procissões, penitências e demais disciplinas que antecediam feriados religiosos ou calamidades anunciadas como as pestes "que Dios les envía por castigo de sus culpas". Os sacramentos administrados aos fiéis e aos

Anos 90, Porto Alegre, v. 11, n. 19/20, p.225-257, jan./dez. 2004 
"A su usanza y según el aderezo de la tiera"...

recém-convertidos eram sempre associados a intercessões divinas benéficas que produziam o consolo e o apaziguamento das consciências dos indígenas. Apesar de resultarem de um "processo de construção de sentido", a assistência às missas, a participação nas procissões e festas religiosas e as penitências e autoflagelações eram apresentadas, no discurso jesuítico, como indícios da adesão aos valores cristãos e como demonstração pública da interiorização e assimilação da "civilização dos afetos e da conduta" pretendida pelos missionários.

A análise que fizemos dos registros que integram as Cartas Ânuas aponta para a possibilidade de compreendermos as reduções jesuítico-guaranis como espaço de acomodação de sensibilidades, desfazendo a percepção da sujeição absoluta dos indígenas aos valores cristãos e às condutas ocidentais. Acreditamos que, no processo de civilização/conversão dos Guarani - o qual implicou o "viver em redução" -, os missionários definiram estratégias e manejaram símbolos e valores; os resultados, no entanto, estiveram condicionados às motivações e às aspirações dos indígenas.

As manifestações de piedade e de devoção não devem ser, em razão disso, percebidas como, exclusivamente, estratégias de sobrevivência. É inegável que os Guarani, movidos pelo senso de oportunidade e conscientes de que as reduções garantiam a preservação da vida física, tornaram-se receptivos à mensagem cristã que lhes prometia a vida eterna. Os registros dos missionários, além disso, apresentam elementos que nos permitem concluir que os Guarani buscaram o atendimento de sua espiritualidade e a expressão de sua sensibilidade valendo-se de práticas e representações tradicionais, que foram ressignificadas, como fica demonstrado no "chorar copioso", nos lamentos fúnebres, nos sonhos e nas visões, bem como nas manifestações de alegria e júbilo por ocasião das missas e das festas religiosas com adornos e bailes, "a su usanza".

Como bem observou Chartier, as práticas e as palavras que pretendem moldar os pensamentos, as condutas e gestos não são totalmente eficazes, uma vez que seus sentidos e significados são ativamente apreendidos por aqueles que delas participam. A aceitação

Anos 90, Porto Alegre, v. 11, n. 19/20, p.225-257, jan./dez. 2004 
e a recusa "das mensagens e dos modelos opera-se sempre através de ordenamentos, de desvios, de reempregos singulares" (Chartier, 1990, p.137), que ultrapassam as próprias prescrições e recomendações.

Em sua obra $A$ invenção do cotidiano, De Certeau fala-nos da capacidade que existe na ação do homem ordinário, que recria, no cotidiano, práticas de vida. A isso o autor chamou de reinvenção do cotidiano, que "é astuciosa, é dispersa, mas ao mesmo tempo [...] se insinua ubiquamente, silenciosa e quase invisível, pois não se faz notar com produtos próprios, mas na maneira de empregar os produtos impostos por uma ordem dominante" (De Certeau, 1994, p.39). Ao analisar aspectos da história construída no cotidiano por indivíduos desprezados como protagonistas desses relatos históricos, De Certeau resgata-os como personagens que, através de táticas, organizam as "maneiras de jogar em campo alheio", das quais deixam vestígios que apontam para marcas de subjetividade nas ações que desenvolvem. Referindo-se aos usos e consumos de "bens culturais", o jesuíta francês observa que "os conhecimentos e as simbólicas impostas são objeto de manipulação pelos praticantes que não são seus fabricantes", das quais resultam "procedimentos de consumo combinatórios e utilitários", caracterizados por uma criatividade tática e bricoladora (De Certeau, 1994, p.95).

Ao considerarmos a experiência reducional numa perspectiva inter-relacional, a compreendemos como um processo de articulação e de negociação, no qual os sujeitos atuaram com suas experiências e, de modo fundamentalmente criativo, reinterpretaram um discurso recebido, produzindo um novo discurso e reapropriando-se do espaço organizado. Não desconhecemos, no entanto, que os saberes etnológicos, geográficos e científicos de que os missionários eram detentores foram poderosos instrumentos de ordenação do mundo indígena para incorporá-lo progressivamente à civilização cristã ocidental. Reconhecemos, igualmente, que os missionários desenvolveram constantemente mecanismos de controle das interpretações possíveis e aceitáveis. Por outro lado, para que se torne convincente e verossímil, todo sentido depende de um acordo sobre

Anos 90, Porto Alegre, v. 11, n. 19/20, p.225-257, jan./dez. 2004 
"A su usanza y según el aderezo de la tiera"...

os signos utilizados e, portanto, ele é necessariamente intersubjetivo, expressando-se na experiência comum compartilhada e no exercício comum da linguagem.

Pierre Bourdieu já demonstrou que a prática não pode ser deduzida exclusivamente das regras; ela deve ser tomada, ao contrário, como uma improvisação, como um aprendizado do uso de determinadas regras, no qual as "maneiras de ver e o contexto estão associados e se implicam mutuamente" (Bourdieu, 1990, p.21). Nessa perspectiva, acreditamos que as manifestações de devoção registradas nas Cartas Ânuas, além de apontarem para a ressignificação de práticas e representações tradicionais guaranis, devem ser tomadas como resultantes de jogos de relações sociais e de comunicação, nos quais os indivíduos em interação, embora pertencentes a universos culturais distintos, necessariamente compartilharam símbolos, códigos e experiências. Somos, em razão disso, levados a concordar com Melià, para quem o êxito das reduções jesuítico-guaranis não se deu "a pesar de lo que eran los Guaraníes, sino precisamente por lo que eran estos Guaraníes" (1986, p.209).

"A su usanza y según el aderezo de la tierra"- baroque devotion and pity in Jesuit-Guaranis missions

Abstract. The paper analyzes the Jesuit discourse trough its gaps, introducing the Jesuit-Guarani settlements ( $17^{\text {th }}$ century) as a space of reinvention of meanings, where a specific sensitiveness was built as consequence of a selective and creative appropriation and of a ressignification of expressions of the native Guarani culture and the Christian-occidental culture. The research found that the specific demonstrations of Guarani's sensitivity were assumed by Jesuit discourse, as a result of a successful converting process to Christianity.

Keywords: Jesuit discourse. Jesuit-Guarani settlements. Native Guarani culture.

\section{Notas}

${ }^{1}$ Sobre as fontes utilizadas na realização deste trabalho, salientamos que os estudos encontrados na historiografia brasileira e ibero-americana sobre as reduções jesuítico-guaranis na Província do Paraguai, especialmente sobre seu período de

Anos 90, Porto Alegre, v. 11, n. 19/20, p.225-257, jan./dez. 2004 


\section{Eliane Cristina Deckmann Fleck}

implantação e consolidação, constituem-se em produção abundante. Em sua grande maioria, caracterizam-se pela preponderância factual e política, determinando uma abordagem descritiva dos aspectos das organizações econômica e social próprias desse processo histórico, como se pode observar nas obras de Pablo Pastells (1912), Pablo Hernández (1913) e Guillermo Furlong (1962). Entre os poucos estudos que abordam as temáticas deste trabalho numa perspectiva social e cultural, mais especialmente em relação aos Guarani, podemos destacar os de León Cadogan, Egon Schaden, Branislava Susnik e Bartomeu Melià, que consideramos fundamentais para a compreensão da realidade reducional.

${ }^{2}$ De acordo com Melià , um dos temas que mereceria estudos mais aprofundados "es la indagación sobre el grado de creatividad y de interiorización que las formas de la vida católica han podido alcanzar entre los Guaraníes de las Reducciones" (Melià; Nagel, 1995, p. 197). Esse autor considera fundamental o aporte da Antropologia na realização desses estudos, na medida em que são pautados por questões como: “¿En qué y a qué quedó 'reducido' el Guarani cuando entró en la Reducción? ¿No habían sido más bien algunas de las estructuras y modo de ser guarani las que aseguraron el éxito de la experiencia reduccional?” (ibid., p. 78). ${ }^{3}$ Entre as fontes primárias impressas, utilizamos crônicas de viagens, em especial, as de Ulrich Schmidl e Alvar Cabeza de Vaca, as Cartas Ânuas da Província Jesuítica do Paraguai (referentes ao período de 1609 a 1675), crônicas jesuíticas, como a obra Conquista Espiritual, do Pe. Antônio Ruiz de Montoya, e a obra Viagens às Missões Jesuiticas e Trabalhos Apostólicos, do Pe. Antonio Sepp. Ressaltamos que as Crônicas Jesuíticas, especialmente as que se referem à segunda metade do século XVII, serão utilizadas para cotejar os dados trazidos pelas Ânuas, bem como para ampliar as possibilidades de investigação sobre as reduções jesuítico-guaranis no século XVII.

${ }^{4}$ As considerações feitas sobre as Instruções do Pe. Diego de Torres Bollo, que orientaram a implantação do modelo reducional na região abrangida pela Província Jesuítica do Paraguai, não pretenderam esgotar a análise dos registros acerca da prática missionária jesuítica junto aos Guarani. As expressões de sensibilidade religiosa serão retomadas no contexto das reduções jesuítico-guaranis, a partir das manifestações de piedade e de devoção, bem como das representações perceptíveis no discurso jesuítico. As Cartas Ânuas da Província Jesuítica do Paraguai serão, em razão disso, o corpus privilegiado para a análise que nos propusemos a fazer e para revelar a "construção" de uma sensibilidade religiosa próprias das reduções jesuítico-guaranis.

${ }^{5}$ Ressaltamo que, incapazes de compreender a lógica e a função dessas crenças e desses rituais, os missionários "diabolizaram-nos", não reconhecendo sua importância para os Guarani horticultores, sujeitos às forças da natureza e preocupados em assegurar a fecundidade e a fertilidade da terra, bem como em controlar o tempo futuro que os presságios pudessem antecipar.

Anos 90, Porto Alegre, v. 11, n. 19/20, p.225-257, jan./dez. 2004 


\section{"A su usanza y según el aderezo de la tiera"...}

${ }^{6}$ Essas descrições remetem-nos aos pregadores medievais que temperavam seus sermões com histórias aterrorizantes das repetidas aparições do Diabo para tentar os fracos e levar os pecadores renitentes, como também aos palcos medievais, onde criaturas grotescas com chifres e cauda encenavam num ambiente recendendo a enxofre. Cabe observar que "el indígena conformará su propia imagen del demonio cristiano", difundida pelos missionários jesuítas em seus sermões. Essa descrição revela que "tiene el demonio la facultad de mostrarse visiblemente", "fuera de la típica del ser diabólico", aparecendo "con ocasionales figuras antropomórficas o zoomórficas” (Martini, 1990, p. 175-227).

${ }^{7}$ As estratégias retóricas empregadas pelos missionários apontam para a intenção de fazer circular mensagens de forma que atingissem o maior número de receptores, cuja eficácia ficava na dependência de prévio conhecimento dos interesses e histórias de vida do seu "público-alvo". Daí, podermos considerar os "espaços de interação" como lugar de atualização da intersecção entre o campo da produção e o campo da recepção.

${ }^{8} \mathrm{O}$ simbolismo mais significativo da culpabilidade está associado ao tribunal "transposto metaforicamente para o foro interior", tornando-se "aquilo a que chamamos a consciência moral", "ela própria uma consciência graduada de culpabilidade" (Delumeau, 1989, p. 64). Havia, ainda, a profunda "conexão entre acusação e consolação", na medida em que "Deus ameaça e protege"; "o deus que dá proteção é o deus moral: ele corrige a desordem aparente da distribuição dos destinos, ligando o sofrimento à maldade e a felicidade à justiça. Graças a esta lei da retribuição, o deus que ameaça e o deus que protege são um só e mesmo deus, e esse deus é o deus moral" (ibid., p. 444).

${ }^{9}$ Huizinga (1924, p.198) ressalta que as lágrimas, segundo São Bernardo, eram "as asas da oração [...], o vinho dos anjos", mas que, "em presença dos outros", deveriam ser evitados "estes sinais de devoção extraordinária” que perturbavam os sermões e impediam, muitas vezes, o prosseguimento da liturgia.

${ }^{10}$ Os sentidos são tomados como elementos a dificultar a salvação da alma, logo, seu controle possui a função explícita de robustecer o espírito. O intelecto, em um ato de vontade, deveria subjugá-los, ordenando os afetos e restringindo os prazeres considerados inferiores. Para Loyola, a noção da pureza da alma ligava-se, necessariamente, à manutenção da "pureza corpórea", através do "disciplinamento dos sentidos".

${ }^{11}$ Loyola (1977, p.26) definia a autoflagelação como "castigar la carne, es saber, dándole dolor sensible, el cual se da trayendo cilicios o sogas o barras de hierro sobre las carnes, flagelándose o llagándose". Os motivos elencados por Loyola para que fossem feitas penitências eram três: para satisfazer os pecados passados; para que os sentidos obedecessem à razão; e para buscar uma graça ou dom que a pessoa desejava. Ao desviante, era apresentada a penitência, sacramento por excelência de purificação, uma vez que visava reparar os danos que o pecado causaria à alma.

Anos 90, Porto Alegre, v. 11, n. 19/20, p.225-257, jan./dez. 2004 


\section{Eliane Cristina Deckmann Fleck}

${ }^{12}$ É válido lembrar "a crença no poder expiatório da missa, considerada a mais sublime oração nos diversos níveis culturais da época moderna. [...] Antes mesmo da Reforma, a missa constitui o rito central do Cristianismo na Europa. Muito divulgada é a crença em seu poder expiador, reparador e na sua eficácia para aplacar a ira divina e alcançar a pacificação no plano social, a elevação espiritual e, notadamente, a salvação da alma" (Campos, 1996, p. 66).

${ }^{13}$ Cabe aqui retomar o décimo artigo da $1^{\text {a }}$ Instrução do Pe. Diego de Torres Bollo, de 1609, que recomendava que somente os fiéis assistissem à missa. Neste caso, a punição dos fiéis omissos ou ausentes devia-se ao fato de potencialmente estarem retornando ao seu "antigo costume", o que poderia comprometer não só

"a fortaleza da fé" de muitos, mas também a conversão futura de outros.

\section{Referências}

BOURDIEU, Pierre. Coisas ditas. São Paulo: Brasiliense, 1990.

BURKE, Peter. Cultura popular na Idade Moderna. São Paulo: Cia. das Letras, 1989.

CAMPOS, Adalgisa Arantes. Irmandades mineiras e missas. Varia Historia, Belo Horizonte, n. 16, p. 66-76, 1996.

CHARTIER, Roger. A bistória cultural: entre práticas e representações. Lisboa: Difel, 1990.

CUNHA, Manuela Carneiro da. Antropologia do Brasil: mito, história, etnicidade. São Paulo: Brasiliense, 1987.

DE CERTEAU, Michel de. A Escrita da história. Rio de Janeiro: Forense Universitária, 1982. A invenção do cotidiano: artes de fazer. Petrópolis: Vozes, 1994. v. 1.

DELUMEAU, Jean. História do medo no Ocidente: 1300-1800: uma cidade sitiada. São Paulo: Cia. das Letras, 1989.

DOCUMENTOS DE GEOHISTÓRIA REGIONAL (D.G. R.). Cartas Ânuas de la Província Jesuítica del Paraguay (1641-43). Resistência, Chaco: Instituto de Investigaciones Geohistóricas, n. 11, 1996.

DOCUMENTOS PARA LA HISTORIA ARGENTINA (D.H.A.). Cartas Anuas de la Provincia del Paraguay, Chile y Tucumán de la Provincia de la Compañía de Jesús. 1615-1637. (Iglesia). Buenos Aires: Casa Jacobo Peuser, Tomo XX, 1924.

Anos 90, Porto Alegre, v. 11, n. 19/20, p.225-257, jan./dez. 2004 


\section{"A su usanza y según el aderezo de la tiera"...}

FURLONG S. J., Guillermo. Misiones y sus pueblos de guaranies. Buenos Aires: Imprenta Balmes, 1962.

HUIZINGA, Johan. O declínio da Idade Média. Lisboa: Ulisséia, 1924.

JAEGER S. J., Odilon. A liturgia nas reduções dos guaranis. Perspectiva Teológica, Ano II, n. 3, p. 203-204, 1970.

LEONHARDT S. J., Carlos. (Trad.). Cartas Annas de la Provincia del Paraguay (Año de 1668). Buenos Aires, 1927a.

(Trad.). Cartas Anuas de la Provincia del Paraguay - Año de 1669 a 1672. Buenos Aires, 1927b. Mimeografado.

(Trad.). Cartas Anuas de la Provincia del Paraguay de la Compañia De Jesús, de 1672 a 1675. Buenos Aires, 1927c.

(Trad.). Cartas Anuas de la Provincia del Paraguay (Año de 1668). Buenos Aires, 1927d. Mimeografado.

LOYOLA, Ignacio. Ejercicios espirituales. Asunción: Centro de Espiritualidad Santos Mártires, 1977.

MAEDER, Ernesto J. A. (Org.). Cartas Ânuas de la Provincia Jesuitica del Paraguay (1637-39). Buenos Aires: FECIC, 1984.

Cartas Anuas de la Província del Paraguay, 1632-1634. Buenos Aires: Academia Nacional de la Historia, 1990.

MARTINI, Monica P. Imagem del Diablo en las reducciones guaranies. Revista Investigaciones y Ensayos, Buenos Aires, n. 40, p. 335-359, 1990.

MATEOS, F. El Primer Concilio del Río de la Plata en Asunción (1603). Missionalia Hispánica, v. XXVI, n. 78, p. 257-359, 1969.

MELIÀ, Bartomeu. El guaraní conquistado y reducido: ensaios de etnohistoria. Prólogo de Demétrio Núñez Gómez. Asunción: Biblioteca de Estudios Antropológicos de la Universidad Católica, 1986.

; NAGEL, Liane Maria. Guaranies y jesuitas en tiempo de las Misiones: una bibliografia didáctica. Santo Ângelo, RS: URI, Centro de Cultura Missioneira; Asunción: CEPAG, 1995.

MONTOYA, Antonio Ruiz de. Conquista espiritual. Porto Alegre: Martins Livreiro, 1985.

PASTELlS S. J., Pablo. Historia de la Compañia de Jesús en la Provincia del Paraguay. Madrid: Librería General de Victoriano Suárez, 1912. Tomo I.

Anos 90, Porto Alegre, v. 11, n. 19/20, p.225-257, jan./dez. 2004 


\section{Eliane Cristina Deckmann Fleck}

PESAVENTO, Sandra. Sensibilidades no tempo, tempo das sensibilidades. Nuevo Mundo, Mundos Nuevos, n. 4, 2004. Disponível em: <www.ehess.fr/ cerma/Revue/indexcr.htm>.

RABUSKE S. J., Arthur. A Carta Magna das reduções jesuíticas guaranis. Estudos Leopoldenses, UNISINOS, v. 14, n. 47, p. 21-39, 1978.

RESENDE, Maria Leônia Chaves de. Jesuítas: os mestres do Neengatú. Estudos Ibero-Americanos, PUCRS, v. XXV, n. 1, p. 244-245, 1999.

REVEL, Jacques. Os usos da civilidade. In: CHARTIER, Roger (Org.) História da vida privada: da Renascença ao Século das Luzes. São Paulo: Cia. das Letras, 1991. p. 180-190.

SAHLINS, Marshall. Ilhas de história. Rio de Janeiro: Zahar, 1990. 